\title{
Soviet Traders-Bureaucrat, and New Bussiness Men in Russia
}

本論文は複数のレフェリーの塞査を受けたものです。

\section{ソ連官僚貿易人とロシア新ビジネスマン}

敦賀女子短期大学恩田 久 雄

1.はじめに

旧ソ連の外国貿易分権化は、ペレストロイカの 一貫として1987年 1 月 1 日以降、従来の外国貿易 省とその金下貿易公団以外に、21の省・国家委員 会とアカデミ一附属の68企業が、外国貿易を直接 取扱う権利を認められたことにより始まった。つ いで西側企業との合弁・ショイントベンチャーの 許可、個人の外貨所有容認、登録者への貿易活動 自由化、地方行政府への許認可権分与などの流れ が続いた。

ソ連邦崩壤、C I S国家間の内外資産分割争い、 援助国から被援助国への転落、政治経済の混迷、 社会不安の高まりが旧ソ連の全土を覆ら中で外国 貿易も混乱した。ロシア連邦政府は、重要戦略物 資の輸出入承認制（'91.12.31）と貿易による取 得外貨の一定比率（'93.7.1 現在、ロシア全 土一率50\%）を強制的にルーブルに兌換させる外 貨コントロールを通じて中央集権的手法に回帰し 貿易秩序の回復と外貨収支の改善を図ろらとして いる。

しかし威令は行われず、巨額（200億ドル規模） の海外逃避資金 (Capital flight)の発生など、 無法状態が随所に出現している。

国家独占一分権化一中央統制、とめまぐるしく 変化する中で、貿易従事者（ソ連時代の官僚貿易 人と市場経済への移行過程下のロシアに新しく誕 生したビジネスマン) は、どら変っているのか、 あるいは変らないか、主としてその対外交涉ビへ イビアの特性に見られる変化は何かを考察し、そ こから導き出される知的支援等のあり方について も付言する。

レーニンの強い主張により始められた貿易の国 家独占 ${ }^{11}$ は、やはりレーニンにより強い指弾を受 けた貿易従事者の官僚的特性 2)を引きずり続けて ソ連邦の崩壊に至った。崩壊の衝撃によって、ペ
レストロイカ期以降の貿易従事者は、ついにその 官嘹的特性を厸拭したのであろらか。

“新ビジスマン”と時に自称する彼等には、 その出身母体や貿易業務に就く以前の職種・職場 の如何を問わず、概ね共通してプラスイメージと マイナスイメージが認められる。ビジネスに際し て、ロシアの経済・社会・国家をどらするのか、 その中で自らのビジネの在り方は? と広い発想 とそれなりのビジネスモラルを身につけているか、 あるいはビジスの目的は唯一自己の金儲けにあ りとして手段を選ばないか、によってイメージが 異なってくる。一般に前者のプラスイメージの者 は一部の少数者で、後者のマイナスイメージの者 が多数者と認められている。事実は当然に、同一 人がマクロの視野とエゴイズムの立場の相剋に時 に悩み時に悩みもなく、激変混沌の世を泳いでい る者もいる、と見るのが妥当であろら。マイナス イメーシの“新ビジネスン”と見られている者 の或る部分は、明らかに“経済マフィア”と呼ば れて敬遠され恐怖の対象と一般市民から思われて いる者の一部でもあろう。

2.ソ連官僚貿易人とロシア新ビジネスマンの交 渉特性

ペレストロイカ期以前の “ソ連外交の交涉特性” については、マイケル・ブレーカー氏の簡潔な分 析がある゙゚。

同氏の分析は多くの点で “ソ連官僚貿易人の交 涉特性”之読み替えてほとんど通用するものであっ た。ここでは新ビジネスマンが官嘹貿易人の交涉 特性を引き継いでいるか、変化しているか、の考 察を次の視点から行ってみたい。

○国家目標とビジネスの合理性・採算性

○大国意識

○官僚的気稹（傲慢と小心） 
○情報・能力の上部集中と属人性

○リスクヘの関心と対応

○独占の強みと弱み一強者の恫喝と弱者の恫喝

(1)国家目標とビジスの合理性・採算性

貿易が社会主義国家としての第○次五力年計画 に示された自国経済なり社会主義友好国支援のた めの国家目標に奉仕するためのものであった時代 には、ビジネスの合理性・採算性にはしばしば二 次的・三次的意義しか与えられていなかった。体 制崩壊一国家目標の衰失下では、新ビジネスマン にとっても輸出入許可の取得に際して一応関係官 僚の示す承認条件をクリヤ一する必要はある。実 態は、許可一件につき数万ドル単位の贈賄によっ てしばしば解決され、専ら独自の採算性によりビ ジスの諾否が決せられている。大統領はじめ国 家指導者層の誰もが明確な国家目標を示していな い現状では、この第三者にはしばしば不可解な “独自の採算性”を基準とする新ビジスマンが 多数派であるのもやむを得ないであろう。国家目 標を当然明確に反映されて然るべき、武器輸出に ついてすら、しばしば違法・不法にロシアにとっ て極めて不利な“独自の採算性”にもとずいて取 引されている、と政府当局者は嘆いている。

\section{（2）大国意識}

超大国ソ連の崩壊と引き続く政治释済の混乱、 被援助国への転落は国民の大国意識を傷つけた。 混迷する社会状況下にあって、スラブ大民族を主 張する新しい民族主義の高まりもあり、大国主義 との決別を実現したと単純に見るのは早計である。

「今ロシアに協力し奉仕しておけば、ロシアの 大市場に進出可能だが、しなければこの大市場を 失う。遅れて来るものは相手にされない。」と強 引な大国意識の変化球を投げまくる新ビジネスマ ソも結構多い。官僚貿易人と少しも変わっていな い交涉姿勢のワンパターンである。米欧韓にはそ れに応えて取引拡大・合弁企業設立などかなり積 極策を示したパートナーも現われたが、ロシア側 にピジネス遂行上必要な諸条件・基盤を欠いてい
るため、成果の見通しを得るに至らず、撤収した ケースも多(4)。

\section{（3)官僚的気質}

繁文縟礼・硬直的・権威主義・形式にこだわっ て時間を惜しまない、なとの官僚的気質を表現す る言葉は多く、何れもソ連官僚貿易人気質を評す るのに適していた。ここではその傲慢と半面の小 心が新ビシネスマンにおいてどう変化したか、を 見たい。

内外に対する“貿易の国家独占”の立場から、 “競争するビジネスマソ”に転じた彼等には、「国 家権力を笠に着た傲慢さは確かに希薄となり、大 国家組織の中で泳ぐプロセスで身につけた小心さ も、表面的には目立たなくなった」、と新ビジネ スマンの交渉振りをモスクワの日本商社マンは証 言する。

当たりはやわらかくなり、時には大胆な発想と 約束もするが、その約束を簡単に反古にすること も多く安心出来ない。近代的な市場経済の底辺を 支える“信用”の重要性を理解していない者も多 い。その最たるものは、多額の貿易債務の支払い 遅延であり、契約条件の度重なる変更である。

傲慢と小心は、余り見えてこなくなったが、代 りに不信用性に悩まされることになっている゙。

（4)情報・能力の上部集中と属人性

ソ連時代のタテ割り官僚社会では、情報は上へ 上へと集中して流れ、上から下への流れは指令に 付属した限定情報に限られた。個人の能力も上昇 志向で上へ行く程高くなるのが一般的であり貿易 関係機関も例外ではなかった。そこから重要案件 の交涉は「ボス」との直接談判が効果的となる。 『ボスは常に正しい』と彼等が複雑な笑いととも に発する言葉は、その官僚制の風刺であるととも に、能力・情報量に優れたボスの実体を反映する 言葉でもあったのである。

登録さえすれば自由に貿易業務に参入できる分 権体制下では、任意の組織・機関が情報・能力の 有無やその質・内容とは殆ど無関係に、ハードカ 
レンシーを入手できる点のみに引かれて貿易業務 を開業できることとなった。対外交渉の必要性や その効果として、第一線の比較的若年層に情報や 能力が集まっているケースが多い、認められる。 『ボスはシャープカ（帽子）だ』とは、国有財産 をとり込んで新企業の基盤とし、政府高官を抱き 合せにとり込んでその会長とし、自らは経営の実 体を牛耳る新ビジネスンの言葉である゙。

前者を逆ピラミット型とし後者をピラミッド型 と見れば、市場経済により弾力的に順応できる企 業体システムとしては、新ビジネスマンの集う現 在の型により大きな可能性が認められよう。ただ し“人的コネクション”を異常な程に尊重するロ シア人の性癖が、しばしば組織や権限の枠を超え て実体を動かすことがあるので、型にとらわれず、 企業体内外の特定個人に必要な情報や能力が属し ている、と割り切った方がより現実的な対応が可 能となることは昔も今もあまり変らない。

\section{(5)形式主義一文書主義}

官嘹貿易人にとって、“形式を重んじ文書を尊 重する”ことは、何よりも優先事項であった。現 実を合理的に有意味に処理することは時として二 の次、三の次であった。

貿易契約書は、原則として全ソ商工会議所が作 成し承認したロシア語による契約フォームによる ことを条件として例外を嫌い、外国パートナーか らの新条件記載要求は極力拒否し、時には威嚇で 退けた。その一方で、文書で約束したこと、契約 書に正式調印した契約の条件は極力守る努力を確 かにしたことが認められた。

新ビシネスマンは、おおむね形式主義の衣は脱 ぎ捨てたと思ってよい。その一方で、文書で約束 し契約書に調印しても、時として、「状況が変わっ たから」の一言であっさりと約束を反古にし、専 ら自己により有利な方向に走る傾向が強い。市場 経済を支えている“契約”と“信用”の観念がま るっきり身についていないのである。抗議をした ら、「大統領令が少しも守られていない我が国だ から仕方がない」と肩をすくめただけ、という5)。
業を煮やしたアメリカと韓国のパートナーは関 係省大臣や国家委員会議長の履行保証を求めてそ のサインを取り付けたものの、やはり契約は条件 通りに実行されなかった事例がある由。伝え聞い た日本商社マンは、さらばとチェルノムイルジン 首相の承認サインを取り付けて、首尾よく契約を 遂行し得た、といら。極く限られた例外であろら か。

文書主義の良い面は、新ビジネスマンにも先人 から是非引き継いで鿓いたいと、世界中のビジ スパートナーは願っている。

(6)リスクへの関心と対応

貿易取引に密接な関連のあるリスクには、カン トリーリスク・リーガルリスク・コマーシャルリ スクの 3 種類がある。自国内と貿易相手国のこれ らリスクに対して、貿易従事者は絶えず細心の注 意を払わねばなら性質のものである。官僚貿易 人と新ビジネスマンは、これらのリスクへの関心 と対応が明らかに異なってきている。以下にやや 詳しく考察しよう。

カントリーリスク：

官嘹貿易人の時代、ソ連は全世界を先進資本主 義国・社会主義国（友好的社会主義国と非友好的 社会主義国）・発展途上国（社会主義国にとり込 みたい国と然らさる国）に区分して、政治目的最 優先の外交・貿易政策をそれぞれの相手国別に打 ち出していた。その当時は、カントリーリスクは 西側の特殊な概念でソ連には無縁なものとして扱 われており、限られた研究者以外はその言葉も知 らなかった。特に超大国ソ連が“健在”であった 時期には自国のカントリーリスクの自覚は貿易人 でも殆どなく、また実際に西側評価機関のリスク レイティングでもかなり上位（優位）を占めてい た時期があった。

新ビジネスマンの時代に、ロシアはカントリー リスクの概念と自国に対するその評価の厳しさを 知ることになった。世銀・IMFをはじめ各国金 融専門家との金融支援策打ち合せの都度、そして 内外の対ロシア市場経済移行支援セミナーの都度、 
ソ連官僚貿易人とロシア新ビジスマン

政治経済社会の全般にわたるカントリーリスクの 評価項目ごとにロシアの評点向上への努力を求め られ約束させられてきた。

$\mathrm{E}$ ・ヤコブレワ・ロシア科学アカデミー世界経 済国際関係研究所幹部研究員（経済学博士候補） は、『経済と生活』誌（1993年 8 月 No.33）に ユーロマネー誌（ロンドン，1993年 3 月）の報じ たカントリーリスク・ランキングを引用して広く 紹介した。

以下はヤコブレワが “旧社会主義国の資本投資 期待度ランキング”として紹介したユーロマネー 誌の169力国中の順位とその評点である。ヤコブ レワは、これに対して「ロシアは最近、外国資本 の集中対象としての、それでなくとも弱い自己の ポシションを失った。…ロシアは149位におかれ （1992年 9 月は129位)、しかもこの最下位グルー プにはザイールやベラルーシ、カサフスタン、ア ルバニア、北朝鮮、ウズベキスタンのような国も 入っているのである。ロシアを旧社会主義国とし て、また旧ソ連の連邦構成共和国として、リスト の下位に押し込んでいるのである。」解説して いる。

$$
\text { ・ユーロマネー誌のカントリーリスク・ランキ }
$$
ング（1993年 3 月）

$$
\text { <順位 }>\quad \text { 評点 }>
$$

\section{アジア諸国}

$\begin{array}{lrr}\text { 中国 } & 42 & 60.73 \\ \text { ベトナム } & 123 & 23.95 \\ \text { モンゴル } & 144 & 19.20 \\ \text { 北朝鮮 } & 151 & 16.73\end{array}$

旧東欧コメコン諸国

$\begin{array}{lrl}\text { ハンガリー } & 47 & 54.92 \\ \text { チェコ } & 48 & 54.89 \\ \text { スロバキア } & 56 & 45.32 \\ \text { ルーマニア } & 74 & 36.94 \\ \text { ポーランド } & 78 & 35.78 \\ \text { ブルガリア } & 118 & 24.78\end{array}$

旧ユーゴスラビア連邦共和国

$\begin{array}{lrr}\text { スロペニア } & 63 & 42.19 \\ \text { クロアチア } & 110 & 26.36\end{array}$

セルビア・チェルノコリア

$132 \quad 21.96$

ボスニア・ヘルツェコビナ

$139 \quad 20.62$

旧ソ連邦

\begin{tabular}{lll} 
エストニア & 126 & 23.35 \\
ラトビア & 133 & 21.70 \\
リトアニア & 134 & 21.36 \\
キルギス & 142 & 19.91 \\
ウクライナ & 145 & 19.17 \\
ベラルーシ & 147 & 18.75 \\
カザフスタン & 148 & 18.55 \\
ロシア & 149 & 18.13 \\
\hline ウズペキスタン & 152 & 16.37 \\
グルジア & 155 & 15.57 \\
トルクメニスタン & 156 & 15.28 \\
モルドワ & 159 & 14.05 \\
タシキスタン & 160 & 13.80 \\
アゼルバイジャン & 161 & 13.66 \\
アルメニア & 162 & 13.58
\end{tabular}

第 1 位は日本99.44、第169位はキューバ6.75

新ビジネスマンが、あ大規模プロジェクトの 協議の場で日本側に対して、「ロシアのカントリー リスクの評価を知りたい。それはG 7 の対ロシア 支援にどう影響しているか？」と質問した由であ る。ようゃく支援の基礎的条件についての理解が かみ合らか、と思わせる。

リーガルリスク：

官嘹貿易人は、自国および貿易相手国の法規制 に神経を使っていた。特に自国の法規制違反は時 に嶶罰を覚悟せねばなら奴ことから、各企業組織 の法務担当は細心の注意を払っていた。

新ビジネスマンは、大統領令・法律・閣僚会議 決定の何れもが朝令暮改を繰り返して、特に経済 
関係法の未整備が主因で、遵法精神がいちじるし く希薄となっている。「法律なぞあるかないか分 らない今のうちにしっかり稼ぐのだ。」と公言す るのは、輸入商品の転売で巨利を収めた新ビジネ スマンである。「彼等に遵法精神を体得させるに は、強権発動でむりやり堅い枠にはめ込む他ない のでは？それがエネルギーを失わせて、せっかく 消費市場に出廻ってきた商品が再び消え去らない か？一体誰に強権をもたせるのか？」一旧最高会 議の議論ではなく、日本商社モスクワ駐在員の感 想である。

コマーシャルリスク :

官僚貿易人も取引相手（特に私企業）のコマー シャルリスクには或程度の注意を払った。相手先 の倒産などによる契約不履行・債権回収不能など の事態む時折発生し不測の損失を受けた経験から である。

新ビジネスマンは、内外環境の激変の中でより 深い注意をコマーシャルリスクに払わさるを得な くなっている。とくにその警戒心は、1990年以降 に創設され始めて1993年 4 月 1 日現在ロシア全土 で1769行となった各種商業銀行にまず向けられた。 銀行の機能不全が主因の事故多発により、銀行と 取引すること自体が “金融的自殺”と呼ばれる程 に不確かで信用できるものでなくなったことによ る。日本企業の被害も発生している。外貨資金の 海外逃避（capital flight）やその引出しによる 多額の第三国経由決済取引の存在は、“国内銀行 の不信用”を物語っている。

そこで『情報センター・レイテング社』（1991 年 3 月創業・モスクワ）が主要商業銀行の信用度 を調査してその格付を発表する業務を始めた。そ の格付ランキングは、A・B・Cの 3 カテゴリー とし各カテゴリーをさらに $3 \cdot 2 \cdot 1$ の 3 クラス に分け、合計 9 ランキングとしている。最近（19 93.10.29)発表のロシア商業銀行カテゴリー別行 数は次の通りであった。
A 3 （信用度最高級）
6 行
A 2
11 行
A 1
15行
B 3
40 行
B 2
81 行
B 1
75 行

以上のA 3 - B 1 の評価を得た 228 行の行名は 同誌上に発表されているが、“当てにならない” ランキングのCカテゴリーの行名は発表されてい ない, ${ }^{6}$ 。

『レイテング』誌自体の評価はいまだ定まって いないが、その作業成果は今後内外の関心を集め よう。さらに同様の格付機関が、『レイテング』 社以外にも複数創設されて、銀行だけでなく商品 取引所・主要な他業種、特に外国貿易進出企業の 信用度格付と公表を行う機関の創設が望ましい。 その際、ロシアの市場経済移行を促す知的インフ ラの一つとして、日米欧の合弁企業その他の形に よるノウハウの提供が望ましい。それは、西側世 界がロシアの新ビジネスマンとビジネス界におけ る常識の共有二価値の共有を促す重要なテコとな ろっ。

独占の強みと弱み一強者の恫喝と弱者の恫喝： 官僚貿易人の時代は、生産の中央管理を背景に 貿易の国家独占体制によって、国内的には無競争 で超大国ソ連を全面に押し出して、外国の互いに 競争し合っている多数の貿易パートナーに対して 強い立場で交涉に臨んだ。パートナーの取捨選択 は専ら独占側にあったからである。しかし、国内 での無競争は、技術開発・経済発展への刺激を失 わせて、情報公開が進むとともに、その遅れた実 体をさらけだすことになった。独占の強みは重大 な弱みを内包していたのである。

新ビジネスマンの時代、登録だけで新規に貿易 事業に乗り出した企業の多くは、貿易業務に必要 不可欠なノウハウ・経験を持った要員を欠いたま までいきなり国際市場に参入し、対外交渉に臨ん だために、多くの混乱と失敗を招いた。それは輸 出入承認制に関与する中央官僚の取引介入に口実 を与えることにもつながった。官僚による公的財 
産横領・丸抱え外国旅行の強要 - 収賄なと、時に 新ビジネスマンも巻き込んだ不祥事件がひんぱん に伝えられている。

かつての “独占対競争”の強い立場から、“競 争対競争” へと交涉相乎と平等の立場に変わった ことによるあせりや、心理的プレッシャーも、不 祥事件へと新ビシネスマンを駆り立てる引き金の 一つであろら。

「自分は改革派で貴方の真に良いパートナーと なろらとしているが、まだ弱い。競争相手の保守 派国営企業は強大である。今支援が得られないと 自分はダメになって結局改革は失敗し、自由な市 場経済実現は遠のき、自由世界のマイナスとなる。」 これは“弱い”新ビジネスマンが自分を売り込む 際の論法である。金融的支援を獲得し、合弁企業 設立を要請するときも類似の論法で迫ってくる。

エリツィン大統領やその支持グループが、「我々 民主改革グループを支えてくれなければ、ロシア は再び共産党・保守派が強大となり政治・経済の 混乱が深まって、先進各国や世界の民主主義諸国 に大きな損失となる。」との論法で支援を迫るの と軌を一にしている。ともにロシア的 “弱者”の 恫喝である。

3.ロシア人の見た日本ビジネスマンの交渉姿

\section{勢一欧米韓との比較}

A・ロシオーノフ日ロ経済委員会事務局長は語 $3^{7)}$ 。

「日本ビシネスマンが来て、長く話してそのま ま㷌っていく。何の成約もなしに。“飛び込み” のヨーロッパの会社は地方行政府長官と協定に調 印し、後でこの協定が名ばかりたと分かる。日本 人は協定実現の可能性を $100 \%$ 確信するまで調印 しない。……本の会社と協力を話し合うとき、 時々悲観主義がロシア企業によきる。“彼等はや りたくないんだ、彼等は歩きたさない”と。日本 パートナーの考え方と心理を研究する価値がある。」

筆者の数次にわたるモスクワ・ロシア亟東の取 材旅行から、日本ビジスマンのリスク評価にも とづく完璧主義が、欧米韓パートナーとの交渉姿
勢比較で、ロシオーノフ氏意見となったことが良 く理解できる。欧米韓の事業家・ビシネスマンに とっては、事業は冒険・拙速・失敗の要素を常に 含むもの。混迷の続くロシアでも、今のうちに経 験を蓄積し人的コネクションを築き上げれば将来 のプラス要因となる、と割り切っているかの如く である。リスクを計算予測し対策を講じた後に動 き出す日本型と、いずれがより良い成果を収める か、判断に時が必要である。

\section{4. ロシア支援策一今何が出来るか?}

1）金融支援は、ロシア側とくに保守派・中道 派と見られているグループに拒否反応があり、前 述通り銀行自体の信用に問題があるのに加えて、 ルーブル価値の下落・生産低下・インフレ高進が 依然として続き、支援効果が疑問視されること。 G 7 を中心とする支援国側の経済不振による能力 の限界と、ロシア大国主義復活への反発、東欧諸 国・他のCI S 諸国と発展途上国への配慮などか ら限界に達している。1993年東京サミットで確認 した総計434億ドルが限度であろら。

2）日本が今なすべきは、知的支援に重点を置 き、政府と道拊県ごとの総合的長期的アクション プログラム案をロシアに提示しそれぞれが協議に 入るべきである。最も効果が浸透し、ロシアの変 化を根本から促すのに役立つと思われるのは、日 本国内各企業・官庁・団体などでの実地の業務作 業研修であろう。少人数短期のそれはすでに或程 度行われている。環日本海交流に参画している道 府県は当面それぞれ年間 100 人〜 200 人・1 年間程 度の受入れ研修を実施しては如何か。市場経済下 で守るべき最も重要なものは“信用”と“契約” であることを体得して貴う。今のロシア人にとっ て、特にマイナスイメージのロシアビジスマン にとって、人間改造に等しい変化を期待すること は、一世代か二世代をかけてのことになろらか。 <註>

1）『帝国主義のこの時代においては、どの様な 関税政策も真面目な議論になり得ない。外国 貿易独占のシステムあるのみである。』『合弁 
会社のシステムは、外国貿易人民委員会の不 出来な機関を実際に改善することが出来る唯 一のシステムである。何故ならば、このシス テムの下では、外国商人もロシア商人も一緒 に働くからである。その様な諸条件の下でさ えも、もし我々が少々学び、或いは学びとり、 或いは完全に学びとることが出来ないならば、 我々の国民は全く見込みのない馬鹿者達だ。』 （レーニン全集第 5 版第45巻333頁-337頁、 中央委員会総会のためのスターリン宛手紙一 1924年 1 月26日付)

2）『‥でたらめな事務涉滞につき国家政治保安 局は、その（外国貿易委員会の）責任者を探 し出し、脅かしつけねばならない。モスクワ 経済会議勤務者を 6 時間、外国貿易委員会勤 務者を36時間投獄する様命ずること。（勿論 全ロシア中央執行委員をのぞいて一我々には 議会的不可侵権に近いものがあるのだから） 次に、新聞に委せて、この双方の連中をあさ けり喠を吐きかけること。恥さらしなことに、 モスクワっ子がモスクワで事務沾滞と斗うこ とが出来なかった、ということなのだから。 棍棒で叨いてやらねばならん。ำらしなけ れば、ソビェトの勤務者は地方でも中央でも ましにならないだろら。』

（レーニン全集 5 版第44巻427頁 -430頁、 レーニンのカーメネフ宛手紙ー1922年 3 月 3 日付より)

3 ）『ソ連の交渉態度』『ソ連の政策決定パター ソ』『ソ連のバーゲニングの戦略・戦術』参 照。“根まわしかきまわしあとまわし”マイ ケル・ブレーカー著、池井優訳、サイマル出 版会、1976年、p.p.247-266。

$4 ）$ ロシア対外経済関係省・ロシア企業・合弁企 業・日本商社モスクワ事務所を歷訪聴取。(1 993.11.19-25)
$5 ）$ 1991年 7 月〜1993年 3 月迄にエリッィン大統 領の発した “大統領令” は約 2,000 本の多数 に上る。その他に人民代議員大会採択の“法 律”、閣憭会議決定の “決定” も数多く、相 互に矛盾する内容もあり法体系が乱れている。 この面だけからも国民の遵法精神が、著しく 希薄となっている原因が分かる。尚、1993年 1月 1 日〜11月19日の間に発令された大統領 令は 1,965 本。

6）「レイテング」誌、情報センター・レイテン グ社発行、1993.10.29、モスクワ；および 『フィナンシアル・イズベスチア』1993.10. 1、モスクワ。同誌により “最高信用度A 3” を得たのは次の 6 行である。

$$
\begin{aligned}
& \text { モスビジネスバンク } \\
& \text { モスコフスキー } \\
& \text { インダストリアリヌイバンク } \\
& \text { プロムストロイバンク } \\
& \text { ロッセルホズバンク } \\
& \text { ロシア連邦ズベルバンク } \\
& \text { このうち、“ロッセルホズバンク”（農業融 }
\end{aligned}
$$
資取扱）のニュライ・リ八チョフ頭取は、19 93年12月 2 日、何者かに銃で撃たれ死亡した。 ロシアでは今年に入って銀行幹部を中心に 37 人のビジスマンが殺害された。ロシア銀行 協会は暗殺に抗議して12月 7 日の 1 日間銀行 の臨時閉店を呼びかけ、モスクワのほとんど の商業銀行が休業した。同協会は、「7月に 国に公開書簡を送り捜査の強化を求めたがいっ こうに事態は改善されなかった。保安、内務 当局者は銀行家やビジネスマンを敵とみなし ている。」と休業宣言について述べ、捜査当 局への不信感をあらわにしている。（日本経 済新聞、1993年12月 8 日)

新ビジネスマンを敵視する勢力は、保安・ 内務当局だけでなく、社会に広く存在すると 見られており、明らかにそのマイナスイメー ジ対する反発や羡望が下敷となっている。 また、銀行家を含めた新ビジネスンン自身 
ソ連官僚貿易人とロシア新ビジスマン

が経済マフィアであり、マフィア同士の利権 争いが武斗グループを生み、互いの殺し合い にまで発展している、とする見方も有力であ る。そして、保安・内務当局はマフィア同士 の抗争を鎮める意思も能力もないのが真相た、 とする見方も多い。

7 ）「実業界」誌、モスクワ、1993.5.26。 訳文：「通商シャーナル」、1993年 8 月号、 日貿易協会。 